This paper is published as:

Druckman, A. and T. Jackson (2009). "The carbon footprint of UK households 1990-2004: a socio-economically disaggregated, quasimultiregional input-output model." Ecological Economics 68 (7): 20662077.

\title{
The carbon footprint of UK households 1990-2004: a socio-economically disaggregated, quasi-multi-regional input-output model
}

\author{
Druckman, Angela ${ }^{\mathrm{a}}$; Jackson, Tim ${ }^{\mathrm{a}}$. \\ ${ }^{a}$ ESRC Research Group on Lifestyles, Values and Environment (RESOLVE) \\ University of Surrey (D3), Guildford GU2 7XH, UK \\ Tel: +44 (0)1483686679; Fax: +44 (0)1483686671
}

*Corresponding author

a.druckman@surrey.ac.uk

\begin{abstract}
This paper presents a socio-economically disaggregated framework for attributing $\mathrm{CO}_{2}$ emissions to people's high level functional needs. Based around a quasi-multi-regional input-output (QMRIO) model, the study, in theory, takes into account all $\mathrm{CO}_{2}$ emissions that arise from energy used in production of goods and services to satisfy UK household demand, whether the emissions occur in the UK or abroad. Results show that $\mathrm{CO}_{2}$ emissions attributable to households were 15\% above 1990 levels in 2004, and that although absolute decoupling occurred between household expenditure and $\mathrm{CO}_{2}$ during the UK's switch from coal to gas in the early 1990s, since then only slight relative decoupling is evident. The proportion of $\mathrm{CO}_{2}$ that arises outside UK borders in support of UK consumption is rising, and reducing these emissions is particularly problematic in a global trading system. Investigation into the carbon footprint of different segments of the UK population shows wide variation: the segment with the highest carbon footprint emits $64 \%$ more $\mathrm{CO}_{2}$ than the segment with the lowest. Results show that recreation and leisure are responsible for over one quarter of $\mathrm{CO}_{2}$ emissions in a typical UK household in 2004. We conclude that expanding lifestyle aspirations are significant factors in driving household $\mathrm{CO}_{2}$ emissions, but the study also emphasizes that attention must be paid to the infrastructures and institutions that result in considerable amounts of $\mathrm{CO}_{2}$ being locked up in basic household activities through which people meet their everyday needs for subsistence, protection, and communication with family and friends. The findings highlight the sheer scale of the challenge facing UK policy-makers, and suggest that policies should be targeted towards segments of society responsible for the highest carbon footprints.
\end{abstract}

Keywords: carbon footprint; input-output analysis; UK; households; decoupling; socioeconomic segmentation.

\section{Introduction}

The premise of this study is that the responsibility for carbon dioxide $\left(\mathrm{CO}_{2}\right)$ emissions from economic activity lies with people's attempts to satisfy certain functional needs 
and desires. In simple economic terms, our needs and desires are expressed in the consumer demand for commodities, and it is this demand for goods and services which drives the production processes that consume resources - including energy resources and emit pollutants - including $\mathrm{CO}_{2}$ and other greenhouse gases (Daly 1996; Daly and Cobb 1989; HM Government 2005; UN 2002; UNCED 1992). To help us understand the link between the attempted satisfaction of human needs and desires and $\mathrm{CO}_{2}$ emissions, and to understand the scale of emissions reductions that are required, we ask the following questions. How much $\mathrm{CO}_{2}$ is attributable to which kinds of needs and desires? Is the highest amount attributable to subsistence needs such as food and clothing? Or protection (housing and security)? Or our leisure demands? Or to the need to communicate with our family and friends? Do some segments of UK society have a higher carbon footprint ${ }^{1}$ than others? If so, what is the disparity? What are the current trends, and to what extent is decoupling occurring between household expenditure and $\mathrm{CO}_{2}$ emissions?

In order to be able to start to answer these questions we present a framework that estimates $\mathrm{CO}_{2}$ emissions from energy use attributable UK households from the consumption perspective. We apply this framework for three investigations: (a) trends 1990-2004; (b) $\mathrm{CO}_{2}$ emissions by different segments of society; (c) we explore the amounts of $\mathrm{CO}_{2}$ that are used to support the various different activities that make up modern lifestyles, or, in other words, we attribute $\mathrm{CO}_{2}$ emissions to functional uses.

In accounting from the consumption perspective we include $\mathrm{CO}_{2}$ emissions from energy used directly in homes (for space heating, lighting, and so on), for personal transportation (including personal vehicle use and personal aviation), and also from energy used upstream in the production of goods and services purchased by UK households (Bastianoni et al. 2004; Bin and Dowlatabadi 2005; Jackson and Papathanasopoulou 2008; Jackson et al. 2006; Munksgaard and Pedersen 2001; Nijdam et al. 2005; Peters and Hertwich 2006; Peters 2008; Weber and Matthews 2008). The upstream $\mathrm{CO}_{2}$ emissions are referred to as "embedded". An important aspect of the consumption perspective is that it takes account of all emissions incurred in support of household consumption within the UK, whether they occur in the UK or abroad (Druckman et al. 2008a; Wiedmann et al. 2008a; Wiedmann et al. 2008b). This contrasts with the production perspective, which accounts for emissions produced within UK territorial boundaries, regardless of where consumption of final goods and services occurs. The difference between the two approaches is the $\mathrm{CO}_{2}$ embodied in trade.

One of the reasons that consumption accounting is not used more widely is that accounting for $\mathrm{CO}_{2}$ embedded in consumption uses Environmental Input-Output (EIO) modelling. This is a highly data-intensive technique for which there are significant difficulties in compiling robust datasets (Peters et al. 2007), and this is particularly the case for the $\mathrm{UK}^{2}$. Furthermore, in order to take account of $\mathrm{CO}_{2}$ embedded in goods and

\footnotetext{
${ }^{1}$ In this paper we define a 'carbon footprint' as the carbon dioxide from energy use attributable to people's activities in attempting to meet their functional needs. This draws on the definition by Wiedmann and Minx (2007). It has the limitation of excluding other environmental stressors such as non$\mathrm{CO}_{2}$ greenhouse gas emissions and land use change, but the benefit of clarity (Weidema et al. 2008).

${ }^{2}$ The latest authorised comprehensive dataset available as a basis for EIO for the UK is for 1995 (Druckman et al. 2007; ONS 2008a). It is possible to use Supply and Use Tables which have been published annually up to 2004 for some of the information required (Lenzen et al. 2004; Wiedmann et al. 2008a).
} 
services produced abroad to support UK consumption, a Multi-Regional Input-Output model (MRIO) is ideally required. MRIO models present even greater data challenges than conventional EIO models, and are often limited in the number of sectors (Huppes et al. 2006; Tukker et al. 2006; Turner et al. 2007). To overcome this difficulty we have developed a quasi-multi-regional input-output (QMRIO) model which attempts to estimate $\mathrm{CO}_{2}$ emissions due to imported goods and services with maximum accuracy and transparency but with lower data requirements than a multi-regional model.

The paper is organised as follows. In the Background section we give an overview of relevant conditions specific to the UK, augment the rationale for the study, give an overview of the socio-economic segmentation system used, and introduce the Local Area Resource Analysis (LARA) model. In Section 3 we describe the methodologies, starting with an overview of consumption accounting, followed by the QMRIO model methodology. The way in which LARA is applied to estimate the average household carbon footprint for each Supergroup is described next (Section 3.2), followed by the methodology for mapping $\mathrm{CO}_{2}$ emissions to high level functional uses (Section 3.3). In the Results section we first look at trends in $\mathrm{CO}_{2}$ emissions (Section 4.1). We then compare the carbon footprints of different socio-economic segments, and investigate how $\mathrm{CO}_{2}$ is used in support of high level functional uses (Section 4.2). The Assumptions and Limitations section comes next (Section 5). In the Discussion we synthesize the salient findings and comment on their relevance for policy-makers.

\section{Background}

As suggested above, a good starting point for investigating $\mathrm{CO}_{2}$ emissions due to consumption is to look at expenditures. UK household expenditure has risen by $49 \%$ since 1990 and, as illustrated in Figure 1, the highest increases have been in Communications, and Recreation and culture (237\% and 195\% respectively). In this paper one of the questions we ask is: to what extent has this increased expenditure resulted in rising energy use and associated $\mathrm{CO}_{2}$ emissions? In other words, has decoupling taken place ${ }^{3}$ ? Decoupling can occur due to technical progress, and one of the drivers that is considered in this paper is the "dash for gas" that occurred in the 1990s in the UK. During this period, due largely to cheap availability of natural gas from the North Sea, the UK electricity industry shifted much of its fuel supply from coal to natural gas, as shown in Figure 2. Other drivers of decoupling can be changes in consumer choices, for example, shifts in household expenditure from highly resource intensive commodities (such as holidays abroad) to lower intensity commodities (such as works of art).

Another aim in this paper is to explore the variation in carbon footprints across different segments of society. There is a wealth of segmentation systems available, many of which are used for commercial marketing purposes and have elements of "lifestyles" encoded within them. These systems are undoubtedly successful for the purposes for which they are designed, but, being commercial, full details are generally not disclosed. Therefore we use the UK National Output Area Classification (OAC) (ONS 2005a; Vickers and Rees 2007; Vickers et al. 2005), chosen for its transparency and robustness. We limit our examination to the $\mathrm{CO}_{2}$ emissions of the top seven OAC Supergroups ${ }^{4}$,

\footnotetext{
${ }^{3}$ Decoupling is defined as 'breaking the link between "environmental bads" and "economic goods", and it can be relative (when the growth rate of the environmentally relevant variable is positive, but less than the growth rate of the economic variable) or absolute (when the environmentally relevant variable is stable or decreasing while the economic driving force is growing) (OECD 2002).

${ }^{4}$ A summary of the salient characteristics of Supergroups is given in the Appendix.
} 
although the methodology is applicable to more detailed levels of segmentation, such as 21 OAC Groups or 52 Sub-Groups. Additionally the methodology can be applied to examine the $\mathrm{CO}_{2}$ emissions of individual small local areas (known as Output Areas, based on Census 2001 boundaries (ONS 2006a)) and through this we could focus on households of extreme affluence and deprivation, and assess measures of inequality (Druckman and Jackson 2008b; Papathanasopoulou and Jackson 2008).

The methodology underlying the analysis of the carbon footprint of Supergroups in this study is the Local Area Resource Analysis (LARA) model. LARA estimates expenditure, resource use and emissions for households in socio-economically homogenous local areas based on their socio-economic characteristics. Druckman and Jackson (2008c) applied LARA to estimate direct household energy use and associated $\mathrm{CO}_{2}$ emissions for Supergroups. They found that both energy and $\mathrm{CO}_{2}$ are strongly, but not solely, related to income levels. Other factors, such as the type of dwelling, tenure, household composition and rural/urban location are also extremely important. In this study we apply LARA to estimate entire carbon footprints, including embedded emissions. Carbon footprints are estimated based on household expenditures as recorded in the Family Expenditure Survey (ONS various years). It is important to take account of total expenditure on all goods and services, as expenditure saved in one area, ostensibly aimed at reducing $\mathrm{CO}_{2}$ (such as savings on fuel bills due to installation of loft insulation), may be spent in another which might have a negative effect on overall $\mathrm{CO}_{2}$ savings. For example, when respondents in a survey were asked how they would spend any savings accrued from lower energy bills, the most common single answer was 'an overseas holiday involving air travel' (NHBC 2008). This phenomenon is known as the rebound effect (Berkhout et al. 2000; Hertwich 2005; Sorrell and Dimitropoulos 2008) and is one of the reasons why it is imperative to take account of consumption of the entire range of goods and services available for purchase in carbon reduction strategies.

\section{Methodology}

\subsection{Consumption accounting}

As introduced earlier, when accounting from the consumption perspective, we take account of $\mathrm{CO}_{2}$ emissions induced by purchases of goods and services within the UK, whether the emissions occur in the UK or abroad. In this paper we account for four broad categories ${ }^{5}$ :

a) $\mathrm{CO}_{2}$ embedded in goods and services purchased by households;

b) $\mathrm{CO}_{2}$ due to direct fuel use by households;

c) $\mathrm{CO}_{2}$ due to personal vehicle use;

d) $\mathrm{CO}_{2}$ due to personal aviation.

We are concerned here only with household consumption as shown by household expenditure. Household expenditure is just one component of final demand in the System of National Accounts (United Nations 1993), the other components being government, fixed capital and exports ${ }^{6}$. There is an argument that all government and fixed capital expenditure is made in support of households (Carbon Trust 2006; Jackson et al. 2006; Jackson et al. 2007; Peters and Hertwich 2004) and therefore analyses

\footnotetext{
${ }^{5}$ In the text we refer only to $\mathrm{CO}_{2}$ emissions but the model is also run for energy use in order to investigate decoupling.

${ }^{6}$ Not for Profit Institutions Serving Households (NPISH) is a further final demand category which is also excluded from the study.
} 
sometimes allocate these expenditures to households. However, in order to draw direct policy implications with regard to households this allocation has not been carried out in the current study.

The choice of the categories above reflects the end uses that we are interested in from a policy perspective. In the category of direct fuel use by households, we include electricity use. Electricity is not, in itself, a fuel: it is an energy carrier, and emissions from its production arise upstream, for example, at power plants where coal, gas or nuclear fuel are burnt. Emissions from electricity used by households are, technically, embedded emissions. However, it is separated from the category of embedded emissions and included as a direct household fuel because this is how it is commonly perceived by consumers, and it is subject to direct household decisions concerning use and savings. Similarly emissions due to personal aviation occur upstream: they have been separated from the general category of embedded emissions due to their significance for emissions reduction policy. ${ }^{7}$

Estimating $\mathrm{CO}_{2}$ due to direct household fuel use, personal aviation and vehicle use is relatively straightforward, and is described in Druckman et al (2008a). Estimation of embedded $\mathrm{CO}_{2}$ is the subject of the next section.

\subsubsection{Embedded $\mathrm{CO}_{2}$ emissions}

In this study accounting for $\mathrm{CO}_{2}$ embedded in expenditure by households is carried out using a quasi-multi-regional input-output (QMRIO) model. Input-output is a well established technique (Leontief 1986; Miller and Blair 1985) and therefore only a brief description of the basic model is given here. Our model is based on the two-region model developed by Proops et al (1993) and Jackson et al (2007), described by the following equations:

$$
\begin{aligned}
& \mathbf{C}^{\mathbf{P}}=\mathbf{u}^{1^{1}}\left(\mathbf{I}-\mathbf{A}^{1}\right)^{-1} \hat{\mathbf{y}} \\
& \mathbf{C}^{\mathbf{Q}}=\mathbf{u}^{2}\left(\mathbf{I}-\mathbf{A}^{2}\right)^{-1} \mathbf{B}^{21}\left(\mathbf{I}-\mathbf{A}^{1}\right)^{-1} \hat{y}^{11} \\
& \mathbf{C}^{\mathbf{R}}=\mathbf{u}^{2}\left(\mathbf{I}-\mathbf{A}^{2}\right)^{-1} \hat{\mathbf{y}}^{21}
\end{aligned}
$$

where

$\mathbf{c}^{\mathbf{P}}$ is the $\mathrm{CO}_{2}$ associated with the flow of goods produced in the UK to meet final demand in the UK;

$\mathbf{c}^{\mathbf{Q}}$ is the $\mathrm{CO}_{2}$ associated with the flow of goods produced in the Rest of the World (RoW) to meet intermediate demand in the UK for goods destined for final demand in the UK; ${ }^{8}$

$\mathbf{c}^{\mathbf{R}}$ is the $\mathrm{CO}_{2}$ associated with the flow of goods produced in the RoW to meet UK final demand;

$\mathbf{u}^{\mathbf{n}}$ is the vector of $\mathrm{CO}_{2}$ coefficients for region $n$;

$\mathbf{y}^{\mathbf{n 1}}$ is the vector of final demand for commodities produced in region $\mathrm{n}$ and consumed in region 1 (the $\mathrm{UK}$ );

$\mathbf{I}$ is an identity matrix;

\footnotetext{
${ }^{7}$ Emissions due to personal travel by trains and ferries is not separated into a category of its own because the per capita levels from these modes of transport are generally lower, and these modes are not so relevant for carbon reduction strategies.

${ }^{8}$ Note that for accounting purposes this flow must exclude the goods required to produce the demand for exports back to the Rest of the World.
} 
$\mathbf{A}^{\mathbf{n}}$ is the "A-matrix" of intra-regional technical coefficients for region $n$. (I-A) ${ }^{-1}$ is known as the 'Leontief Inverse';

$\mathbf{B}^{\mathbf{n 1}}$ is the imports use coefficients matrix for imports from region $n$ to region 1 . This is often referred to as the Imports Use Matrix.

An important shortcoming of most two-region models is the assumption that imported goods have the same production recipe and energy use structure as those produced in the UK (Lenzen et al. 2004). This assumption, known as the 'domestic technology assumption', is described by the following equation:

$\mathbf{u}^{2^{\prime}}\left(\mathbf{I}-\mathbf{A}^{2}\right)^{-1}=\mathbf{u}^{1^{\prime}}\left(\mathbf{I}-\mathbf{A}^{1}\right)^{-1}$

In the QMRIO we modify this assumption so that the $\mathrm{CO}_{2}$ intensity of imported goods more accurately represents the intensity of each of our importing partners, which are divided into 12 world regions. Figure 3 gives a diagrammatic representation of the parameters used to characterise production in 13 regions in the QMRIO model (region 1 is the UK). It shows that imports from region $n$ are characterised by the vector of relative $\mathrm{CO}_{2}$ intensity of region $n$ compared to region $1\left(\mathbf{u}^{\mathbf{n 1}}\right)$, and the vector of the proportion of total imports from region $n$ to region $1\left(\mathbf{p}^{\mathbf{n} 1}\right)$. The industry structure of all regions is represented by the UK A-matrix.

Re-writing equations (2) and (3) in terms of $\mathbf{u}^{\mathbf{n 1}}$ and $\mathbf{p}^{\mathbf{n 1}}$ for a 13 region economy gives ${ }^{9}$

$$
\begin{aligned}
& \mathbf{C}^{\mathbf{Q}}=\sum_{\mathrm{n}=2}^{\mathrm{n}=13}\left(\hat{\mathbf{u}}^{\mathbf{n 1}} \mathbf{u}^{\mathbf{1}}\right) \mathbf{\prime}(\mathbf{I}-\mathbf{A})^{-1}\left(\mathbf{P}^{\mathbf{n} \mathbf{1}} \cdot \mathbf{B}^{\mathbf{i m p}}\right)(\mathbf{I}-\mathbf{A})^{-1} \hat{\mathbf{y}}^{\mathbf{1 1}} \\
& \mathbf{c}^{\mathbf{R}}=\sum_{n=2}^{n=13}\left(\hat{\mathbf{u}}^{\mathbf{n 1}} \mathbf{u}^{\mathbf{1}}\right) \cdot(\mathbf{I}-\mathbf{A})^{-1} \hat{\mathbf{y}}^{\text {imp }} \hat{\mathbf{p}} \hat{\mathbf{n}}^{\mathbf{1} \mathbf{1}}
\end{aligned}
$$

In this paper the QMRIO model given by equations 1, 5 and 6 is applied for an annual time-series $1990-2004^{10}$. Data for non-UK regions are obtained from GTAP (Dimaranan 2006). This dataset is aggregated from 87 regions to 13 regions based on those used by Wilting (2008). Due to problems found with the GTAP $\mathrm{CO}_{2}$ emissions data (see, for example, Peters and Hertwich (2008)), emissions for selected countries are overwritten with data kindly provided by Glen Peters, as described in the same publication. Further details of the QMRIO methodology and datasets are presented in Druckman and Jackson (2008a).

\subsection{Socio-economic disaggregation using LARA}

The result of the procedures explained above is a time-series of $\mathrm{CO}_{2}$ emissions attributable to UK households 1990-2004. We now show how LARA is used to achieve socio-economic disaggregation in order to estimate the $\mathrm{CO}_{2}$ attributable to each Supergroup.

LARA is used to estimate mean household expenditure, direct resource use and associated emissions for small local areas of 124 households on average from the consumption perspective (Druckman and Jackson 2007; Druckman and Jackson 2008c;

\footnotetext{
${ }^{9}$ For details see Druckman and Jackson (2008a).

${ }^{10}$ Data for 1991 were not available, therefore 1991 is excluded.
} 
Druckman et al. 2008b). In this study LARA is applied to each of the 175,434 Output Areas in England and Wales which are then grouped into seven Supergroups. The main characteristics of each of these Supergroups, which have names such as 'Prospering Suburbs' and 'Constrained by Circumstances', are given in Appendix 1.

A schematic diagram showing use of LARA in this study is shown in Figure 4. The lefthand side shows data inputs to LARA. Outputs from LARA used in this study are in terms of $\mathrm{CO}_{2}$ emissions (namely mean $\mathrm{CO}_{2}$ from direct household fuel and vehicle use for each Supergroup) and expenditures. Estimation by LARA of $\mathrm{CO}_{2}$ from direct household fuel use by households in each Supergroup is based on estimates from Druckman and Jackson (2008c). The methodology has been repeated to estimate mean $\mathrm{CO}_{2}$ from personal vehicle use for each Supergroup. $\mathrm{CO}_{2}$ from personal aviation is estimated based on expenditure information on aviation by each Supergroup from LARA. Embedded emissions for each Supergroup are estimated using the QMRIO model, as given in equations 1, 5 and 6 , with household demand for the seven different Supergroups estimated using LARA. Further details are given in Druckman and Jackson (2008a).

Figure 4 also shows how $\mathrm{CO}_{2}$ emissions are allocated to high level functional uses, and this is the subject of the next section, which commences with an explanation of the reasoning underlying the choice categories.

\subsection{Mapping $\mathrm{CO}_{2}$ emissions to high level functional uses}

As discussed above, in this paper we aim to estimate $\mathrm{CO}_{2}$ emissions attributable to high level functional uses. Figure 1 shows expenditures allocated to 12 COICOP $^{11}$ categories (UN 2005). These categories are designed to identify 'functional uses' such as Education, Health and Transport. When considering $\mathrm{CO}_{2}$ involved in supporting UK lifestyles these COICOP categories are not ideal, and therefore we select different high level functional use categories for the purposes of this study, as used by Jackson et al (2006; 2007), and Carbon Trust (2006). The rationale for this selection is in part to reflect the range of material, social and psychological needs that are associated with modern lifestyles (Jackson 2005; Jackson 2008; Jackson and Marks 1999). Some of these are basic functional needs for material subsistence, protection and health. Others are associated more with social needs such as communication and education. Others cover a range of social and psychological motivations for leisure, relaxation, and interacting with friends and family. We therefore use the following categories:

$\begin{array}{ll}\text { - } & \text { Space heating } \\ \text { - } & \text { Fousehold } \\ \text { - } & \text { Clothing \& footwear } \\ \text { - } & \text { Health \& Hygiene } \\ \text { - } & \text { Recreation \& Leisure } \\ \text { - } & \text { Education } \\ \text { - } & \text { Communications } \\ \text { - } & \text { Commuting }\end{array}$

The procedures used for mapping $\mathrm{CO}_{2}$ to these high level functional uses are shown diagrammatically in Figure 4. The Allocation Chart referred to in the diagram is given in Table 1. Figure 4 shows that results from the QMRIO model are in SIC categories.

\footnotetext{
${ }^{11}$ Classification of Individual Consumption According to Purpose.
} 
These are converted to COICOP based on Table 4 ('Households final consumption expenditure by COICOP heading') of the Supply and Use Tables (ONS 2006b). The Allocation Chart (Table 1) is then used as a basis for mapping the COICOP classification onto high level functional uses. For further details see Druckman and Jackson (2008a).

Results from LARA for direct household $\mathrm{CO}_{2}$ by each Supergroup are simply in terms of energy use (gas, electricity and other fuels), but give us no information about the uses for which these fuels are purchased. For this purpose we use information from DTI concerning the amount of each type of fuel used for 'Space heating', 'Water heating',

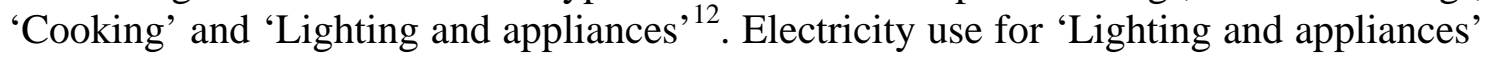
is further disaggregated into use for Lighting, Cold appliances (refrigerators and freezers), Cookers, Brown appliances (such as televisions), Wet appliances (such as dishwashers) and Miscellaneous ${ }^{13}$. Information on these allocations is, to the knowledge of the authors, not available for different types of households based on their socioeconomic characteristics, and therefore mean estimates for the UK are applied to all Supergroups. These categories are then allocated to high level functional uses as shown in Table 1.

$\mathrm{CO}_{2}$ emissions due to personal vehicle use are mapped onto high level functional uses based on information published by the $\mathrm{DfT}^{14}$ on personal travel by purpose which is incorporated into the Allocation Chart (Table 1). Again, UK mean figures are applied for each Supergroup due to lack of socio-economically disaggregated data.

\section{Results}

\subsection{UK national trends 1990-2004}

The first question we address is what are the current trends in UK household $\mathrm{CO}_{2}$ emissions from the consumption perspective? The graph in Figure 5 shows that emissions decreased slightly on average between 1990 and $1994^{15}$. However, since 1999 they have been rising, with levels in 2004 being 15\% higher than those in 1990. In order to explore this in more detail, Figure 6 illustrates trends in total household energy use and $\mathrm{CO}_{2}$ emissions indexed to $1990=100$, alongside household expenditure in constant prices $^{16}$, also indexed to $1990=100$. From this we see that energy use dropped below 1990 levels from 1991 to 1995 , but has been steadily rising since 1997 . Due to the "dash for gas", $\mathrm{CO}_{2}$ emissions decreased at a faster rate than energy use in the early 1990s, and remained below 1990 levels until 2000. However, since then, $\mathrm{CO}_{2}$ emissions have risen at about the same rate as energy use. Household expenditure has risen every year since 1991, with the year on year increase being slightly higher than the increases in energy use and $\mathrm{CO}_{2}$ emissions. From this we can conclude that absolute decoupling occurred between $\mathrm{CO}_{2}$ emissions and expenditure between 1990-1994, but between

\footnotetext{
${ }^{12}$ Source: http://www.dti.gov.uk/energy/statistics/publications/energy-consumption/domestictables/page18071.html Accessed Oct 06.

${ }^{13}$ Source http://www.dti.gov.uk/energy/statistics/publications/energy-consumption/domestictables/page18071.html Accessed Oct 06.

${ }^{14}$ Sources: Trips and distance per person per year by trip purpose (http://www.dft.gov.uk/stellent/groups/dft transstats/documents/page/dft_transstats_612468.hcsp Accessed Oct06); Allocation of shopping trips to purpose is based on DfT (2007).

${ }^{15}$ As noted previously, data for 1991 are not available.

${ }^{16}$ The household expenditure time-series is based on data from Consumer Trends in constant 2003 prices. See http://www.statistics.gov.uk/statbase/product.asp?vlnk=242 downloaded 29.04.08.
} 
1997 and 2004 only very slight relative decoupling is evident, and the current trend is that $\mathrm{CO}_{2}$ emissions from the consumption perspective are rising by around 3\% per year.

Figure 5 shows $\mathrm{CO}_{2}$ emissions in four categories: $\mathrm{CO}_{2}$ embedded in goods and services, $\mathrm{CO}_{2}$ from direct household energy use, and $\mathrm{CO}_{2}$ due to personal vehicle use and aviation. The largest category is embedded $\mathrm{CO}_{2}{ }^{17}$. Its percentage of the total has increased overall with time, commencing at 52\% in 1990, it reached its lowest proportion around 1992-4, before rising to 55\% in 2004. Figure 7 shows the percentage of imported goods and services into the UK in monetary terms, and also the percentage of household embedded $\mathrm{CO}_{2}$ due to imports ${ }^{18}$. This shows that whereas the proportion of imports has only increased marginally in monetary terms, the proportion of embedded $\mathrm{CO}_{2}$ emitted outside UK borders has increased from around 31\% in 1990 to 40\% in 2004.

Figure 5 shows that $\mathrm{CO}_{2}$ from direct household energy use is the next largest category of total emissions after embedded $\mathrm{CO}_{2}$. The proportion due to direct household energy use has decreased over time from 33\% in 1990 to 29\% in 2004, although in absolute terms it is estimated to have been about the same in 2004 as it was in 1990. The largest percentage change over the time period is $\mathrm{CO}_{2}$ from personal aviation, which, although being a small proportion of the total, increased by $86 \%$ between 1990 and 2004 .

Results from the QMRIO model for UK emissions from the consumption perspective compare well with MRIO-based studies by Wiedmann et al (2008a; 2008b), Ahmad and Wyckoff (2003) and Peters and Hertwich (2008). As expected, estimates from the QMRIO model are generally slightly lower than those from MRIO studies due to use of the UK Leontief Inverse for all world regions. Trends agree well with those found by Wiedmann et $\mathrm{al}^{19}$. The advantage of our quasi-multi regional model over multiregional models is that its data requirements are substantially lower, and it has greater transparency. The results from our model also agree well with those found by Kerkhof et al (forthcoming) who used a hybrid approach of process analysis and Input-Output analysis. They estimated annual $\mathrm{CO}_{2}$ emissions for an average UK household to be 20.4 tonnes compared to our estimate of 19.1 tonnes (both for 1998).

\section{2 $\mathrm{CO}_{2}$ emissions for different types of UK households (2004)}

Figure 8 shows mean $\mathrm{CO}_{2}$ for each Supergroup. Emissions from the Supergroup with the highest emissions (Prospering Suburbs) are 64\% higher than those with the lowest (Constrained by Circumstances). The graph also shows that Prospering Suburbs' emissions are $23 \%$ above the $\mathrm{UK}$ mean of $21.5 \mathrm{tCO}_{2}$ whereas Constrained by Circumstances' are 25\% below.

When we look at the relationship between affluence and $\mathrm{CO}_{2}$, we find that, at either end of the income scale, $\mathrm{CO}_{2}$ increases with increasing disposable income levels: for example, the most affluent Supergroup (Prospering Suburbs) has higher emissions than the next most affluent (Countryside), and similarly, the least affluent (Constrained by

\footnotetext{
${ }^{17}$ This figure is lower than figures that are often quoted because this study does not include $\mathrm{CO}_{2}$ emissions due to government and fixed capital expenditures (see Section 3.1).

${ }^{18}$ Imported $\mathrm{CO}_{2}$ includes $\mathrm{CO}_{2}$ emitted abroad in producing goods and services directly consumed by households, and $\mathrm{CO}_{2}$ emitted abroad in producing goods and services to meet intermediate demand by industry for production of goods and services destined for UK household consumption.

${ }^{19}$ For a detailed comparison see Druckman and Jackson (2008a).
} 
Circumstances) has lower emissions than the second least affluent (Multicultural). In particular, Constrained by Circumstances has the lowest emissions from personal aviation, perhaps reflecting that lifestyles entail less foreign travel due to financial constraints. Conversely, Prospering Suburbs and Countryside have the highest emissions from personal aviation, reflecting their relative affluence. Constrained by Circumstances stands out as the Supergroup that has the highest proportion of $\mathrm{CO}_{2}$ due to direct household energy use. These households are expected to be at most risk of being in fuel poverty, which is defined as household that has to spend more than $10 \%$ of its income on energy to heat its home to an adequate standard (DTI 2006). Therefore it is no surprise that a high proportion of the $\mathrm{CO}_{2}$ of these households is, on average, due to direct household energy consumption (BERR 2007; Druckman and Jackson 2008c; Moore 2005; Thumin et al. 2007).

In the middle income groups $\mathrm{CO}_{2}$ is shown to depend on other factors in addition to relative affluence. For example, the disposable income of an average City Living household is about 5\% above that in Blue Collar Communities, but their mean $\mathrm{CO}_{2}$ is lower in all categories (4\% lower overall). With regard to direct household energy use this is assumed to reflect the relative thermal efficiency of flats (which predominate City Living) over terraced housing (which predominate in Blue Collar Communities) (Druckman and Jackson 2008c)). If we look at $\mathrm{CO}_{2}$ embedded in goods and services we find that City Living has the highest proportion of its total in this category, reflecting the relative efficiency of direct energy consumption in urban living (Thumin and White 2008).

Figure 9 shows the proportions of $\mathrm{CO}_{2}$ allocated to high level functional uses for an average UK household. The highest proportion is attributed to Recreation and leisure (26\%). Food and catering and Space heating both account for 15\%, followed by Household (12\%) and Clothing and footwear (11\%). These results are in general agreement with those from other studies, such as Nijdam et al (2005), Peters and Hertwich (2006), and Tukker and Jansen (2006). For example, Tukker and Jansen (2006) found that food, housing (including heating), and transport (which is included largely in recreation and commuting in our study) are generally responsible for around $70 \%$ of total life-cycle impacts. A notable exception is the findings in a US study in which healthcare accounted for a relatively high proportion of $\mathrm{CO}_{2}$ (Weber and Matthews 2008). This is because in the US healthcare is paid privately whereas healthcare it is generally paid for out of taxation in the UK, which is excluded from this study as explained in Section 3.1 .

Investigation of $\mathrm{CO}_{2}$ allocated to high level functional uses for each Supergroup shows that the proportions do not vary a great deal from the pattern of the average UK household. For example, recreation and leisure accounts for $27 \%$ of Prospering Suburbs' overall carbon footprint and 25\% of Constrained by Circumstances'. The similarities in these proportions may, to a certain extent, be due to data limitations in the model (see Section 5). Absolute values attributable to recreation and leisure do, however, vary widely (Prospering Suburbs 7.1tCO $\mathrm{CO}_{2}$; Constrained by Circumstances 4.0 $\mathrm{tCO}_{2}$ ).

So far in this paper we have considered $\mathrm{CO}_{2}$ emissions on a household basis. As discussed above, emissions are generally higher for households with higher disposable incomes but the situation is reversed in the middle income ranges. When we consider 
$\mathrm{CO}_{2}$ on a per capita basis including children the picture changes: on this basis the $\mathrm{CO}_{2}$ ranking is in line with disposable income for all Supergroups. However, if we include only adults over the age of 18 in the count per household, there is very little discrepancy between emissions of the middle ranking households. Table 2 illustrates the difference the accounting basis makes. Although differences are small at the level of Supergroups, larger disparities are expected when the analysis is extended to OAC Groups or Subgroups. This will be important when, for example, considering Personal Carbon Allowances (Roberts and Thumin 2006; Starkey and Anderson 2005), which can be on a household basis, per capita basis, per adult basis, or even on an equivalised basis, with graded weightings assigned to children of different ages (Lunn 2005; McClements 1977; ONS 2005b).

\section{Assumptions and limitations}

This study is subject to the general assumptions and limitations of EIO which are well documented by, for example, Miller and Blair (1985). This section only covers material specific to this study.

As mentioned in the Introduction, the UK lacks authorised up-to-date datasets for EIO and hence all years after 1995 are modelled using the 1995 Leontief Inverse and Imports Use Matrices: therefore changes in industry structure since 1995 are not captured in the model. Furthermore, final demand is not available in Basic Prices. The implications of these data shortcomings are covered in detail in Druckman et al (2008a), and suffice to say here that they are considerable. Data for non-UK regions are obtained from GTAP for 2001, and therefore the relative $\mathrm{CO}_{2}$ intensity and proportion of imports are assumed constant for all years at 2001 levels. This may result in under-estimates of increases in embedded emissions. The inaccuracies that arise in the QMRIO model affect only estimates of embedded emissions, which average 52\% of total emissions over the study period (emissions due to direct household energy use and personal transportation are unaffected as they are not estimated using the QMRIO model). Despite our model's limitations, our results for 2004 are in broad agreement with other studies, as discussed earlier.

For a discussion of the assumptions and limitations in LARA the reader is referred to Druckman and Jackson (2008c) and Druckman et al (2008b). As mentioned above, although through LARA we can identify the functional uses to which embedded $\mathrm{CO}_{2}$ emissions should be allocated for each Supergroup ${ }^{20}$, information is not, at this stage, available to identify the functional uses to which direct energy use and personal transportation emissions should be allocated specifically for each Supergroup. This limits the extent to which we can elicit differences between Supergroups in the amounts of $\mathrm{CO}_{2}$ attributable to high level functional uses.

Compiling the Allocation Chart shown in Table 1 is an interesting exercise in itself and some of the values are open to debate. For example, should all $\mathrm{CO}_{2}$ emissions due to COICOP category 'Catering services' be allocated to high level functional uses 'Food and catering', or should a proportion be allocated to 'Recreation and leisure'? Arguably some attribution to 'Recreation and leisure' may be appropriate, although in this study we have allocated $100 \%$ to 'Food and catering'. Our final estimation of emissions attributed to 'Recreation and leisure' may therefore be under-estimated. Assessment of

\footnotetext{
${ }^{20}$ A caveat to this is that national average values were used for actual and imputed rentals for all Supergroups, as explained in Section 3.2.
} 
$\mathrm{CO}_{2}$ emissions due to aviation are particularly problematic. First, due to the international nature of air travel, many UK citizens book tickets on airlines that are not UK registered companies. The national datasets used in this study include UK registered companies only: we assume that the number of overseas citizens purchasing flights from UK registered airlines balances the number of UK citizens purchasing flights from nonUK registered airlines. Furthermore the boundary between personal flights for recreational purposes and business flights is blurred. This is because many people combine holiday and business trips together, and also some flights are booked personally and then claimed on expenses. In this study we assume that all flights booked by individuals are for personal leisure, and all flights purchased by businesses are used for business purposes only.

\section{Discussion}

In this study we have used a quasi-multi-regional input-output model (QMRIO) to show that, from the consumption perspective, $\mathrm{CO}_{2}$ emissions due to energy use attributable to UK households are estimated to be currently rising by approximately $3 \%$ per annum. This is in stark contrast to the proposed statutory goal in the UK's Climate Change Act of an $80 \%$ reduction in greenhouse gas emissions measured from the production perspective by 2050 (HM Government 2008). During the study period (1990-2004) household expenditure increased by $49 \%$, and we have shown that absolute decoupling between $\mathrm{CO}_{2}$ emissions and household expenditure has not been evident since the early days of the UK's "dash for gas" in the 1990s, although there is currently a small level of relative decoupling. This suggests that technological developments and any of the (sparse) attempts to encourage households to curb their $\mathrm{CO}_{2}$ emissions have been, overall, negated by the rebound effect or by "off-shoring" of carbon-intensive industry. Although some difference between the consumption and production perspectives is to be expected due to trade, it is unrealistic to assume that a global reduction in overall emissions can be achieved while developing countries such as the UK continue to offshore their $\mathrm{CO}_{2}$-intensive industries to less developed countries.

Embedded $\mathrm{CO}_{2}$ accounts for over half of the average UK household's carbon footprint, and this proportion is rising. Furthermore, we estimate that, in 2004, approximately $40 \%$ of embedded $\mathrm{CO}_{2}$ occurred outside UK borders, a proportion that has risen by around 9\% since 1990. This presents a particular problem for UK policy as the extent to which an importing country can control the $\mathrm{CO}_{2}$ intensity of its exports under current World Trade Organisation rules is limited (Pauwelyn and Sindico 2008).

In the study UK households are segmented into 7 Supergroups based on their socioeconomic characteristics. The $\mathrm{CO}_{2}$ emissions of the Supergroups vary widely, and are strongly related to affluence. For example, the most affluent Supergroup (Prospering Suburbs) is responsible for $64 \%$ more $\mathrm{CO}_{2}$ than the least affluent Supergroup (Constrained by Circumstances) on a household basis. Other socio-economic characteristics are also important determinants of $\mathrm{CO}_{2}$ emissions. An example of this is that households in City Living have a relatively low proportion of emissions due to direct household energy use and high proportion embedded in goods and services, reflecting the relative efficiency of direct energy consumption in urban living. Our results illustrate the extreme differences between Supergroups and are indicative of the high levels of inequality that currently exist with respect to $\mathrm{CO}_{2}$ emissions. 
Our study is currently limited in its ability to explore in detail the differences between $\mathrm{CO}_{2}$ emissions due to direct energy use attributable to high level functional uses for each Supergroup. This is because at the moment we do not have information for each Supergroup concerning, for example, the purpose of their personal vehicle use or the relative quantities of electricity that is used for powering, say, household appliances, lighting, and brown goods such as televisions. This is a subject for further investigation, and will be important in targeting specific $\mathrm{CO}_{2}$ reduction schemes at different sectors of society. Not withstanding this limitation, a striking result is that the average UK household emits over a quarter of its $\mathrm{CO}_{2}$ emissions in the pursuit of recreation and leisure (including personal aviation), and the most affluent Supergroup uses the highest amount of $\mathrm{CO}_{2}$ (in real quantities) and also the highest proportion of their total carbon footprint for these activities. Our study makes it clear that the rising aspirations of the UK population for recreation (including leisure travel) are making the task of making genuine progress towards the UK's challenging carbon reduction goals increasingly hard to achieve. However, at the same time, a considerable amount of $\mathrm{CO}_{2}$ is locked up in basic household activities such as heating and maintaining the home, feeding ourselves, commuting to work, and maintaining health and hygiene (Jackson and Papathanasopoulou 2008). In other words, it is probably wrong to place the blame for climate change entirely on rising consumer aspirations. At least some of the responsibility has to rest with the infrastructures and institutions through which ordinary people meet their everyday needs for subsistence, protection, and communication with family and friends.

These remarks are by no means the final word in unravelling the complex mixture of factors that drive modern consumption patterns. However, they serve to illustrate that reducing $\mathrm{CO}_{2}$ emissions attributable to $\mathrm{UK}$ households will require a dedicated and sophisticated effort. In particular, we must strive to increase the use of renewable energy in homes, offices and factories and develop technologies that decouple $\mathrm{CO}_{2}$ emissions from expenditure; to work towards international agreements that will reduce emissions embedded in imports; to reduce the need for everyday car travel; to improve the 'systems of provision' used to deliver functional services; to address the elements of consumer 'lock-in' that leave people powerless to change their lives to reduce their carbon impact; and to find new and innovative ways of meeting consumers' aspirations for recreation and leisure. Without concerted efforts in these areas, it is likely that $\mathrm{CO}_{2}$ emissions attributable to UK households will continue to rise.

\section{Acknowledgements}

We thank Joshua Thumim, Vicki White and Ian Preston at the Centre for Sustainable Energy for provision of fuel price matrices for use in LARA. We thank Peter Bradley, Eleni Papathanasopoulou and Philip Sinclair for their earlier contributions to developing the framework on which this study has built. We are grateful to two anonymous reviewers, whose suggestions greatly improved the paper. The research is supported by funding from the ESRC Research Group on Lifestyles Values and Environment (RESOLVE) (Grant Number RES-152-25-1004), and builds on earlier work supported by funding from the EPSRC Sustainable Urban Environment Waste Consortium programme (Grant Number GR/S79626/01). Data from the 2001 Census are provided 
by the Commissioned Output Census Service of the Office for National Statistics (Crown Copyright 2005).

\section{References}

Ahmad, N. and A. Wyckoff (2003). Carbon dioxide emissions embodied in international trade of goods. Paris, France, OECD.

Bastianoni, S., F. M. Pulselli and E. Tiezzi (2004). "The problem of assigning responsibility for greenhouse gas emissions." Ecological Economics 49(3): 253-257.

Berkhout, P., J. Muskens and Velthuijsen (2000). "Defining the Rebound Effect." Energy Policy 28: 425-432.

BERR. (2007). "The UK Fuel Poverty Strategy 5th Annual Progress Report." Accessed 06.03.08, from http://www.berr.gov.uk/files/file42720.pdf.

Bin, S. and H. Dowlatabadi (2005). "Consumer lifestyle approach to US energy use and the related CO2 emissions." Energy Policy 33: 197-208.

Carbon Trust (2006). The carbon emissions generated in all that we consume. London, UK, Carbon Trust.

Daly, H. and J. Cobb (1989). For the Common Good. Washington DC, Island Press.

Daly, H. (1996). Beyond Growth - The Economics of Sustainable Development. Boston, MA., Beacon Press

DfT. (2007). "Shopping. Personal Travel Factsheet - July 2007." Accessed 24.04.08, from http://www.dft.gov.uk/pgr/statistics/datatablespublications/personal/factsheets/shopping. pdf.

Dimaranan, B. V., Ed(s). (2006). Global Trade, Assistance, and Production: The GTAP 6 Data Base Center for Global Trade Analysis, Purdue University, USA.

Druckman, A., P. Bradley, E. Papathanasopoulou and T. Jackson (2007). "Measuring Progress towards Carbon Reduction in the UK " Ecological Economics (in press).

Druckman, A. and T. Jackson (2007). The Local Area Resource Analysis (LARA) Model. Concepts, Methodology and Applications. RESOLVE Working Paper 02-07, University of Surrey, Guildford, UK. Available from http://www.surrey.ac.uk/resolve/Docs/WorkingPapers/RESOLVE WP 02-07.pdf.

Druckman, A., P. Bradley, E. Papathanasopoulou and T. Jackson (2008a). "Measuring progress towards carbon reduction in the UK " Ecological Economics 66(4): 594-604.

Druckman, A. and T. Jackson (2008a). The Surrey Environmental Lifestyle MApping (SELMA) framework: development and key results to date. RESOLVE Working Paper 08-08, University of Surrey, Guildford, UK. Available from http://www.surrey.ac.uk/resolve/Docs/WorkingPapers/RESOLVE WP 08-08.pdf.

Druckman, A. and T. Jackson (2008b). "Measuring resource inequalities: the concepts and methodology for an area-based Gini coefficient." Ecological Economics 65(2): 242-252.

Druckman, A. and T. Jackson (2008c). "Household energy consumption in the UK: a highly geographically and socio-economically disaggregated model." Energy Policy 36(8): 3177- 3182. 
Druckman, A., P. Sinclair and T. Jackson (2008b). "A geographically and socio-economically disaggregated local household consumption model for the UK." Journal of Cleaner Production 16(7): 870-880.

DTI. (2006). "Energy - its impact on environment and society ", Accessed 07/06/07, from http://www.dti.gov.uk/files/file32546.pdf.

DUKES. (2008). "Fuel input for electricity generation. Table 5.1.1 ", Accessed 07.05.08, from http://www.berr.gov.uk/energy/statistics/source/electricity/page18527.html

Hertwich, E. G. (2005). "Consumption and the Rebound Effect: An Industrial Ecology Perspective." Journal of Industrial Ecology 9(1): 85-98.

HM Government (2005). Securing the future: delivering UK sustainable development strategy. London, UK.

HM Government (2008). Climate Change Act 2008. London, UK, The Stationery Office Limited.

Huppes, G., A. d. Koning, S. Suh, R. Heijungs, L. v. Oers, P. Nielsen and J. Guinée (2006). "Environmental Impacts of Consumption in the European Union: High-Resolution InputOutput Tables with Detailed Environmental Extensions." Journal of Industrial Ecology 10(3): 129.

Jackson, T. and N. Marks (1999). "Consumption, sustainable welfare and human needs--with reference to UK expenditure patterns between 1954 and 1994." Ecological Economics 28(3): 421-441.

Jackson, T. (2005). Lifestyle Change and Market Transformation: A briefing paper prepared for DEFRA's Market Transformation Programme. London, Defra.

Jackson, T., E. Papathanasopoulou, P. Bradley and A. Druckman (2006). Attributing Carbon Emissions to Functional Household Needs: a pilot framework for the UK. International Conference on Regional and Urban Modelling, Brussels, Belgium. 1-2 June 2006.

Jackson, T., E. Papathanasopoulou, P. Bradley and A. Druckman (2007). Attributing UK Carbon Emissions to Functional Consumer Needs: methodology and pilot results. RESOLVE Working Paper 01-07, University of Surrey. Available from http://www.surrey.ac.uk/resolve/Docs/WorkingPapers/RESOLVE WP 01-07.pdf

Jackson, T. (2008). The Challenge of Sustainable Lifestyles. In: State of the World 2008.(Ed(s)) Washington DC, USA, Worldwatch Institute.

Jackson, T. and E. Papathanasopoulou (2008). "Luxury or 'Lock-in'? an explanation of unsustainable consumption in the UK: 1968 to 2000." Ecological Economics 68(1-2): 80-95.

Kerkhof, A., R. M. J. Benders and H. C. Moll (forthcoming). "Determinants of variation in household $\mathrm{CO} 2$ emissions between and within countries." Energy Policy.

Lenzen, M., L. Pade and J. Munksgaard (2004). "CO 2 Multipliers in Multi-region Input-Output Models." Economic Systems Research 16(4): 391.

Leontief, W. (1986). Input-output economics. 2nd Edition. New York, USA, Oxford University Press.

Lunn, S. (2005). "Households Below Average Income Statistics: Adoption Of New Equivalence Scales ", Accessed 10.08.07, from http://www.dwp.gov.uk/asd/hbai/nsfr newequiv.pdf.

McClements, L. (1977). "Equivalence scales for children." Journal of Public Economics 8: 191210. 
Miller, R. E. and P. D. Blair (1985). Input-output analysis : foundations and extensions. Englewood Cliffs, New Jersey, USA., Prentice-Hall.

Moore, R. (2005). "The Fall and Rise of Fuel Prices and Fuel Poverty." Accessed 10.08.07, from http://www.nea.org.uk/downloads/publications/The Fall and Rise of Fuel Prices and Fuel Poverty (FULL REP).pdf.

Munksgaard, J. and K. A. Pedersen (2001). "CO2 accounts for open economies: producer or consumer responsibility?" Energy Policy 29(4): 327-334.

NHBC (2008). Zero carbon: what does it mean to homeowners and housebuilders, NHBC Foundation, Amersham, UK.

Nijdam, D. S., H. C. Wilting, M. J. Goedkoop and J. Madsen (2005). "Environmental Load from Dutch Private Consumption: How Much Damage Takes Place Abroad?" Journal of Industrial Ecology 9(1-2): 147.

OECD (2002). Indicators to Measure Decoupling of Environmental Pressure from Economic Growth. OECD, Paris.

ONS. (2005a). "Area classification for Output Areas ", Accessed 02.06.07, from http://www.statistics.gov.uk/about/methodology by theme/area classification/oa/default asp.

ONS (2005b). Family Spending: A report on the 2003-04 Expenditure and Food Survey. London, UK, Office for National Statistics.

ONS. (2006a). "Geography Policy." Accessed 24.04.06, from http://www.statistics.gov.uk/geography/census geog.asp\#oa.

ONS. (2006b). "Input-Output (I-O) Supply and Use Tables (SUTs) ", Accessed 30.04.08, from http://www.statistics.gov.uk/about/methodology by theme/inputoutput/latestdata.asp.

ONS. (2008). "Consumer Trends." Accessed 29.04.08, from http://www.statistics.gov.uk/statbase/product.asp?vlnk=242

ONS. (various years). "Expenditure and Food Survey ", Accessed 01.06.07, from http://www.statistics.gov.uk/ssd/surveys/expenditure food survey.asp.

Papathanasopoulou, E. and T. Jackson (2008). "Measuring Fossil Resource Inequality - a longitudinal case study for the UK: 1968-2000." Ecological Economics (in press).

Pauwelyn, J. and F. Sindico (2008). "Climate change in a global economy. Editorial." Carbon and Climate Law Review 2(1): 3-6.

Peters, G. and E. Hertwich (2004). Production factors and Pollution Embodied in Trade: Theoretical Development. Norway, IndEcol, NTNU.

Peters, G. and E. Hertwich (2006). "The Importance of Imports for Household Environmental Impacts." Journal of Industrial Ecology 10(3): 89-109.

Peters, G., W. Manshanden and A. Tukker (2007). Report on Technical report focusing on economic data sources for SUT/IO tables for EU25 and RoW, EXIOPOL. Scoping report WP III.2.a and WPIII.3.a

Peters, G. and E. Hertwich, G. (2008). "CO2 Embodied in International Trade with Implications for Global Climate Policy." Environmental Science \& Technology 42(5): 1401-1407. 
Peters, G. P. (2008). "From production-based to consumption-based national emission inventories." Ecological Economics 65(1): 13.

Proops, J. L. R., M. Faber and G. Wagenhals (1993). Reducing CO2 Emissions. A Comparative Input-Output Study for Germany and the UK. Berlin, Germany, Springer-Verlag.

Roberts, S. and J. Thumin (2006). A rough guide to individual carbon trading: the ideas, the issues and the next steps. Report to Defra, Centre for Sustainable Energy, Bristol, UK.

Sorrell, S. and J. Dimitropoulos (2008). "The rebound effect: Microeconomic definitions, limitations and extensions." Ecological Economics 65(3): 636-649.

Starkey, R. and K. Anderson (2005). Domestic Tradable Quotas: a policy instrument for reducing greenhouse gas emissions from energy use, Tyndall Centre for Climate Change Research.

Thumin, J., V. White, Z. Redgrove and S. Roberts (2007). Waste Not, Want Not: Energy Tariffs for Sustainability, WWF, Godalming, UK and Centre for Sustainable Energy, Bristol, UK.

Thumin, J. and V. White (2008). Distributional Impacts of Personal Carbon Trading: A Report to the Department for Environment Food and Rural Affairs. London, UK, Defra, London, UK and Centre for Sustainable Energy, Bristol, UK

Tukker, A., P. Eder and S. Suh (2006). "Environmental Impacts of Products: Policy Relevant Information and Data Challenges." Journal of Industrial Ecology 10(3): 183.

Tukker, A. and B. Jansen (2006). "Environmental Impacts of Products: A Detailed Review of Studies." Journal of Industrial Ecology 10(3): 159.

Turner, K., M. Lenzen, T. Wiedmann and J. Barrett (2007). "Examining the global environmental impact of regional consumption activities -- Part 1: A technical note on combining inputoutput and ecological footprint analysis." Ecological Economics 62(1): 37.

UN (2002). Report of the World Summit on Sustainable Development: Johannesburg, South Africa, 26 August-4 September 2002.

UN (2005). Classification of Individual Consumption According to Purpose, (COICOP). United Nations Statistics Division.

UNCED (1992). "Agenda 21". Rio de Janeiro, Brazil, 3-14 June 1992., United Nations Conference on Environment and Development.

United Nations (1993). System of National Accounts 1993.

Vickers, D., P. Rees and M. Birkin (2005). Creating the National Classification of Census Output Areas: Data, Method and Results, University of Leeds, UK.

Vickers, D. and P. Rees (2007). "Creating the UK National Statistics 2001 output area classification " Journal of the Royal Statistical Society: Series A (Statistics in Society) 179(2): 379.

Weber, C. L. and H. S. Matthews (2008). "Quantifying the global and distributional aspects of American household carbon footprint." Ecological Economics 66(2-3): 379-391.

Weidema, B. P., M. Thrane, P. Christensen, J. Schmidt and S. Løkke (2008). "Carbon Footprint: A Catalyst for Life Cycle Assessment?" Journal of Industrial Ecology 12(1): 3-6.

Wiedmann, T. and J. Minx (2007). A Definition of 'Carbon Footprint. In: Ecological Economics Research Trends. C. C. Pertsova.(Ed(s)) Hauppauge NY, USA., Nova Science Publishers. . Chapter 1, pp. 1-11. 
Wiedmann, T., R. Wood, M. Lenzen, J. Minx, D. Guan and J. Barrett (2008a). Development of an Embedded Carbon Emissions Indicator - Producing a Time Series of Input-Output Tables and Embedded Carbon Dioxide Emissions for the UK by Using a MRIO Data Optimisation System, Report to the UK Department for Environment, Food and Rural Affairs by Stockholm Environment Institute at the University of York and Centre for Integrated Sustainability Analysis at the University of Sydney, June 2008. Defra, London, UK.

Wiedmann, T., R. Wood, J. Minx, M. Lenzen and R. Harris (2008b). Emissions embedded in UK Trade - UK-MRIO Model Results and Error Estimates. The 2008 International InputOutput Meeting on Managing the Environment Seville, Spain.

Wilting, H. C. (2008). Analysis of the Sustainability of Supply Chains with a Multi-Regional InputOutput Model. International Input Output Meeting on Managing the Environment, Seville, Spain, July 9 - 11, 2008. 
Table 1. Allocation table for high level functional uses.

\begin{tabular}{|c|c|c|c|c|c|c|c|c|c|c|c|}
\hline \multirow[b]{2}{*}{$\begin{array}{l}\text { COICOP categories plus } \\
\text { direct use of domestic fuels }\end{array}$} & \multirow[b]{2}{*}{$\begin{array}{l}\text { ClOCOP } \\
\text { category }\end{array}$} & \multicolumn{10}{|c|}{ High level functional uses } \\
\hline & & Household & $\begin{array}{c}\text { Recreation } \\
\& \\
\text { Leisure }\end{array}$ & $\begin{array}{l}\text { Space } \\
\text { Heating }\end{array}$ & $\begin{array}{c}\text { Food } \\
\& \\
\text { Catering }\end{array}$ & $\underset{\text { ing }}{\text { Commut- }}$ & $\begin{array}{l}\text { Health } \\
\& \\
\text { Hygiene }\end{array}$ & $\begin{array}{l}\text { Clothing } \\
\& \\
\text { Footwear }\end{array}$ & Education & $\begin{array}{l}\text { Commun- } \\
\text { ications }\end{array}$ & Total $^{1}$ \\
\hline Food \& Non-alcoholic drink & $1.1,1.2,11.1$ & & & & $100 \%$ & & & & & & $100 \%$ \\
\hline Alcohol \& Tobacco & $2.1,2.2$ & & $100 \%$ & & & & & & & & $100 \%$ \\
\hline Clothing \& Footwear & $3.1,3.2$ & & & & & & & $100 \%$ & & & $100 \%$ \\
\hline Housing & $\begin{array}{l}4.1,4.2,4.3 \\
5.5,5.6\end{array}$ & $100 \%$ & & & & & & & & & $100 \%$ \\
\hline Water Supply \& Other Misc Services & 4.4 & & & & & & $75 \%$ & $25 \%$ & & & $100 \%$ \\
\hline Furnishings \& Other Household & $5.1,5.2,5.4$ & $100 \%$ & & & & & & & & & $100 \%$ \\
\hline Household Appliances & 5.3 & $25 \%$ & $25 \%$ & & $25 \%$ & & $13 \%$ & $13 \%$ & & & $100 \%$ \\
\hline Health \& Hygiene & $\begin{array}{l}6.1,6.2,6.3 \\
12.1\end{array}$ & & & & & & $100 \%$ & & & & $100 \%$ \\
\hline Transport Services (indirect) & $7.1,7.2,7.3$ & $1 \%$ & $40 \%$ & & $5 \%$ & $37 \%$ & $7 \%$ & $6 \%$ & $4 \%$ & & $100 \%$ \\
\hline Post \& Communication & $8.1,8.2,8.3$ & & & & & & & & & $100 \%$ & $100 \%$ \\
\hline Recreation \& Entertainment & $9.1-9.4$ & & $100 \%$ & & & & & & & & $100 \%$ \\
\hline Books \& Newspaper & 9.5 & & & & & & & & $100 \%$ & & $100 \%$ \\
\hline Other Personal Effects & 12.3 & & & & & & & $100 \%$ & & & $100 \%$ \\
\hline Holidays excl dir personal aviation and vehicle use & $9.6,11.2$ & & $100 \%$ & & & & & & & & $100 \%$ \\
\hline Education & 10 & & & & & & & & $100 \%$ & & $100 \%$ \\
\hline Financial \& Other Services & $\begin{array}{l}12.4,12.5,12.6 \\
12.7\end{array}$ & $100 \%$ & & & & & & & & & $100 \%$ \\
\hline Delivered Fuels (indirect) & $4.5{\text { (part })^{2}}^{2}$ & $11 \%$ & $6 \%$ & $48 \%$ & $9 \%$ & & $13 \%$ & $13 \%$ & & $1 \%$ & $100 \%$ \\
\hline Space Heating & & & & $100 \%$ & & & & & & & $100 \%$ \\
\hline Water Heating & & & & & & & $50 \%$ & $50 \%$ & & & $100 \%$ \\
\hline Cooking & & & & & $100 \%$ & & & & & & $100 \%$ \\
\hline Electricity (lighting) & & $100 \%$ & & & & & & & & & $100 \%$ \\
\hline Electricity (cold appliances) & & & & & $100 \%$ & & & & & & $100 \%$ \\
\hline Electricity (brown goods) & & & $90 \%$ & & & & & & & $10 \%$ & $100 \%$ \\
\hline Electricity (wet appliances) & & & & & & & $50 \%$ & $50 \%$ & & & $100 \%$ \\
\hline Electricity (misc) & & $100 \%$ & & & & & & & & & $100 \%$ \\
\hline Personal vehicle use & & $1 \%$ & $40 \%$ & & $5 \%$ & $37 \%$ & $7 \%$ & $6 \%$ & $4 \%$ & & $100 \%$ \\
\hline Personal aviation & & & $100 \%$ & & & & & & & & $100 \%$ \\
\hline
\end{tabular}

\footnotetext{
${ }^{1}$ Discrepancies in totals are due to rounding errors.
}

${ }^{2}$ COICOP category 4.5 includes emissions from electricity production, which are excluded from this domestic functional category as they included directly elsewhere. 
Table 2. Comparison of emissions on different accounting bases (2004).

\begin{tabular}{|c|c|c|c|c|c|c|}
\hline & \multicolumn{3}{|c|}{ Mean carbon dioxide emissions (tCO2) } & \multirow[b]{2}{*}{$\begin{array}{l}\text { Mean number } \\
\text { persons per } \\
\text { household }\end{array}$} & \multirow{2}{*}{$\begin{array}{c}\text { Mean number } \\
\text { persons }>18 \\
\text { years old per } \\
\text { household }\end{array}$} & \multirow{2}{*}{$\begin{array}{c}\text { Disposable } \\
\text { income rank } \\
\text { (1=highest } \\
\text { income })\end{array}$} \\
\hline & Per household & Per capita & $\begin{array}{l}\text { Per capita }>18 \\
\text { years old only }\end{array}$ & & & \\
\hline 1 Blue Collar Communities & 19.5 & 8.0 & 10.7 & 2.4 & 1.8 & 5 \\
\hline 2 City Living & 18.7 & 8.3 & 10.6 & 2.2 & 1.8 & 4 \\
\hline 3 Countryside & 24.9 & 10.2 & 12.9 & 2.4 & 1.9 & 2 \\
\hline 4 Prospering Suburbs & 26.5 & 10.4 & 13.3 & 2.5 & 2.0 & 1 \\
\hline 5 Constrained by Circumstances & 16.1 & 7.4 & 9.6 & 2.2 & 1.7 & 7 \\
\hline 6 Typical Traits & 22.4 & 9.2 & 11.9 & 2.4 & 1.9 & 3 \\
\hline 7 Multicultural & 18.2 & 7.7 & 10.4 & 2.4 & 1.8 & 6 \\
\hline UK Mean & 21.5 & 9.0 & 11.6 & 2.4 & 1.8 & \\
\hline
\end{tabular}

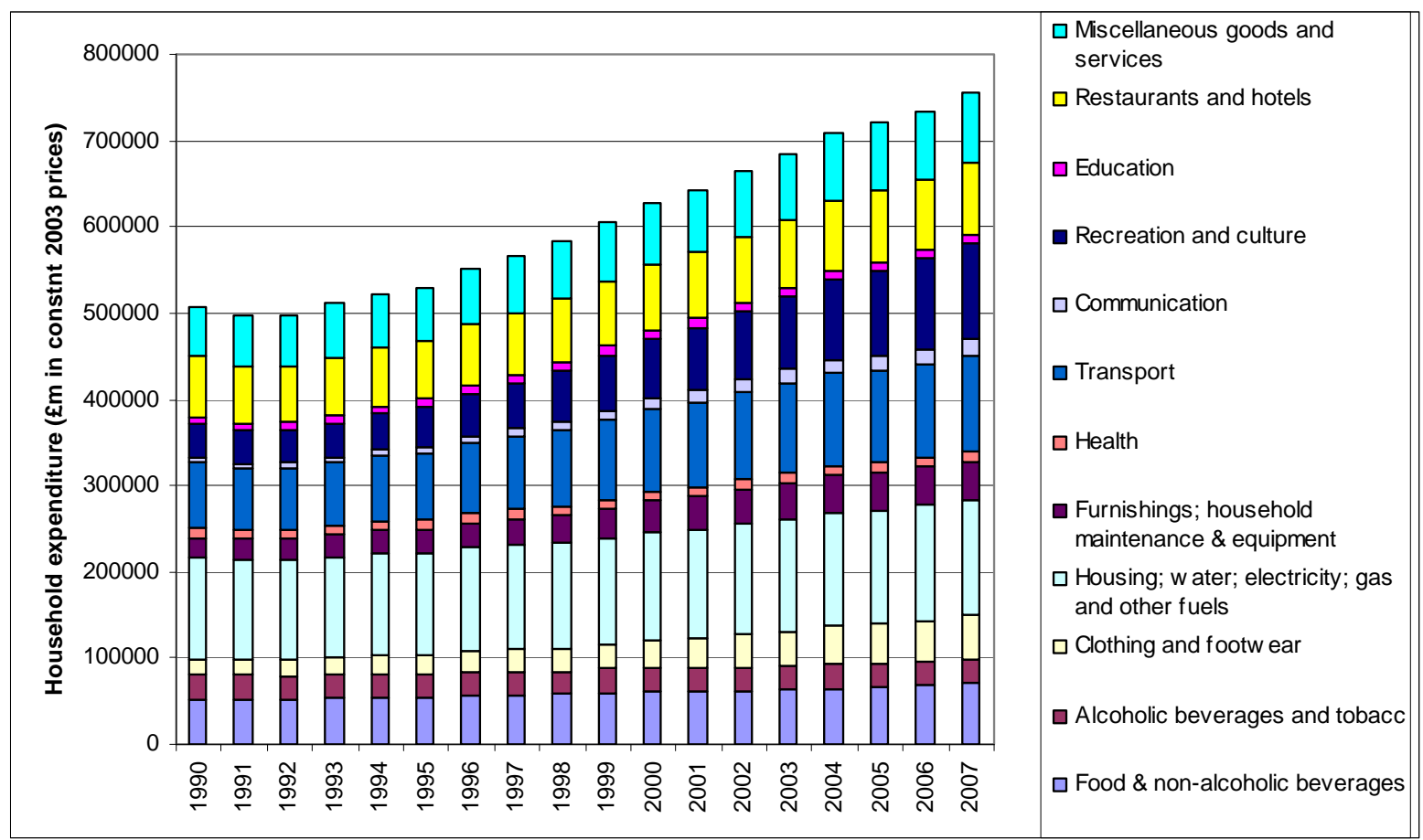

Figure 1. UK household expenditure 1990-2007.

Source: ONS (2008) 


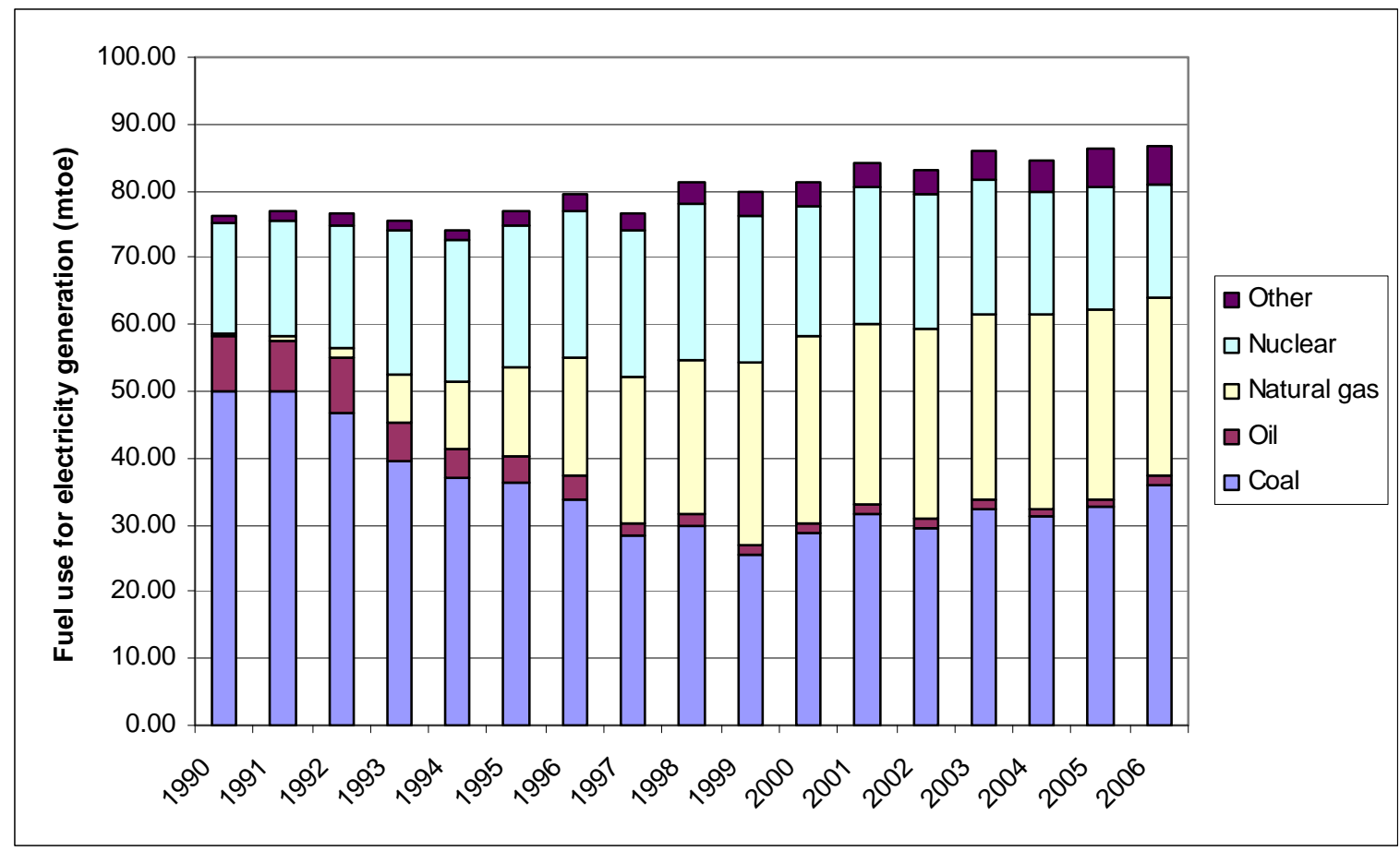

Figure 2. Fuel use for electricity generation 1990-2006.

Source: DUKES (2008)

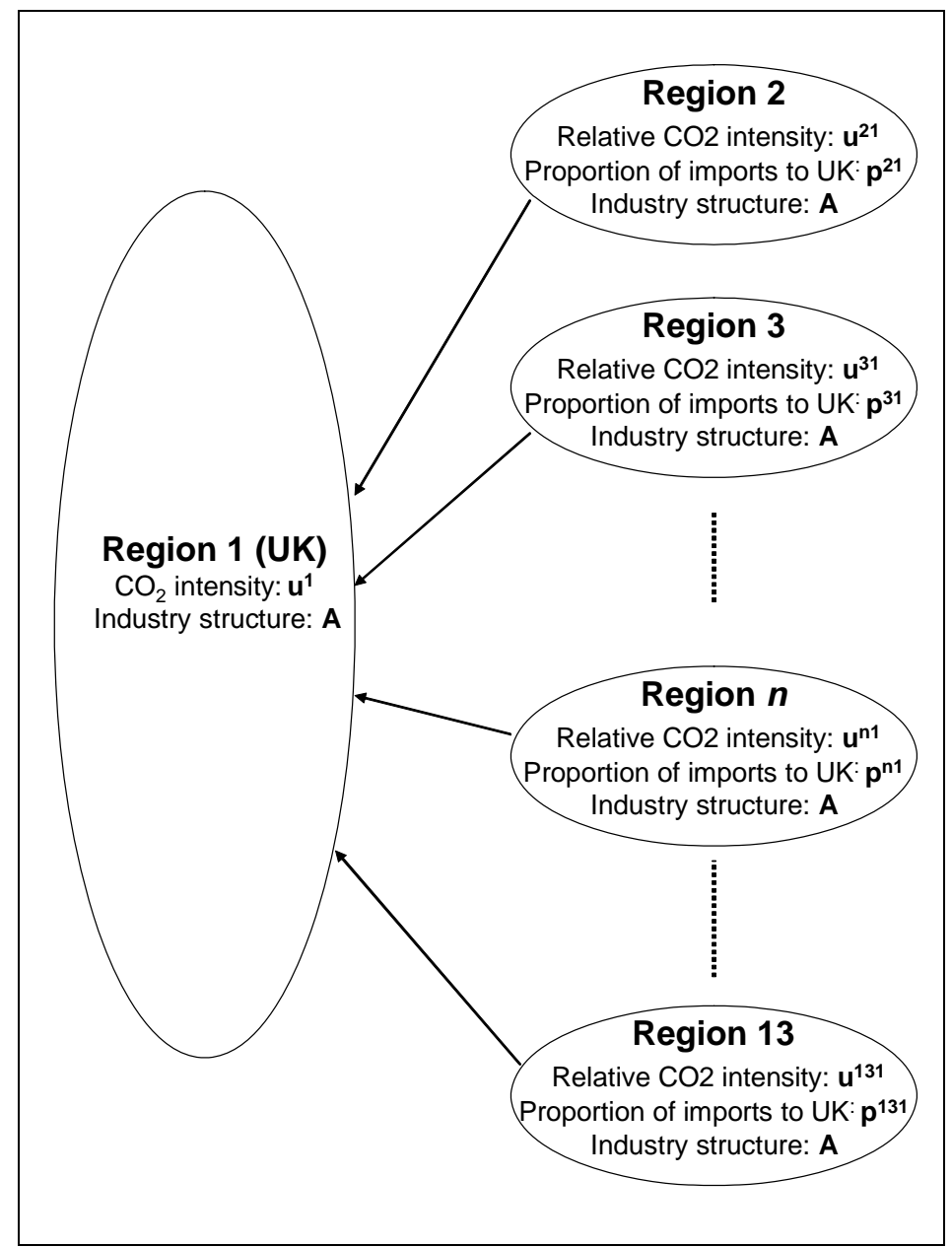

Figure 3. Parameters used for modelling a 13-region QMRIO model 


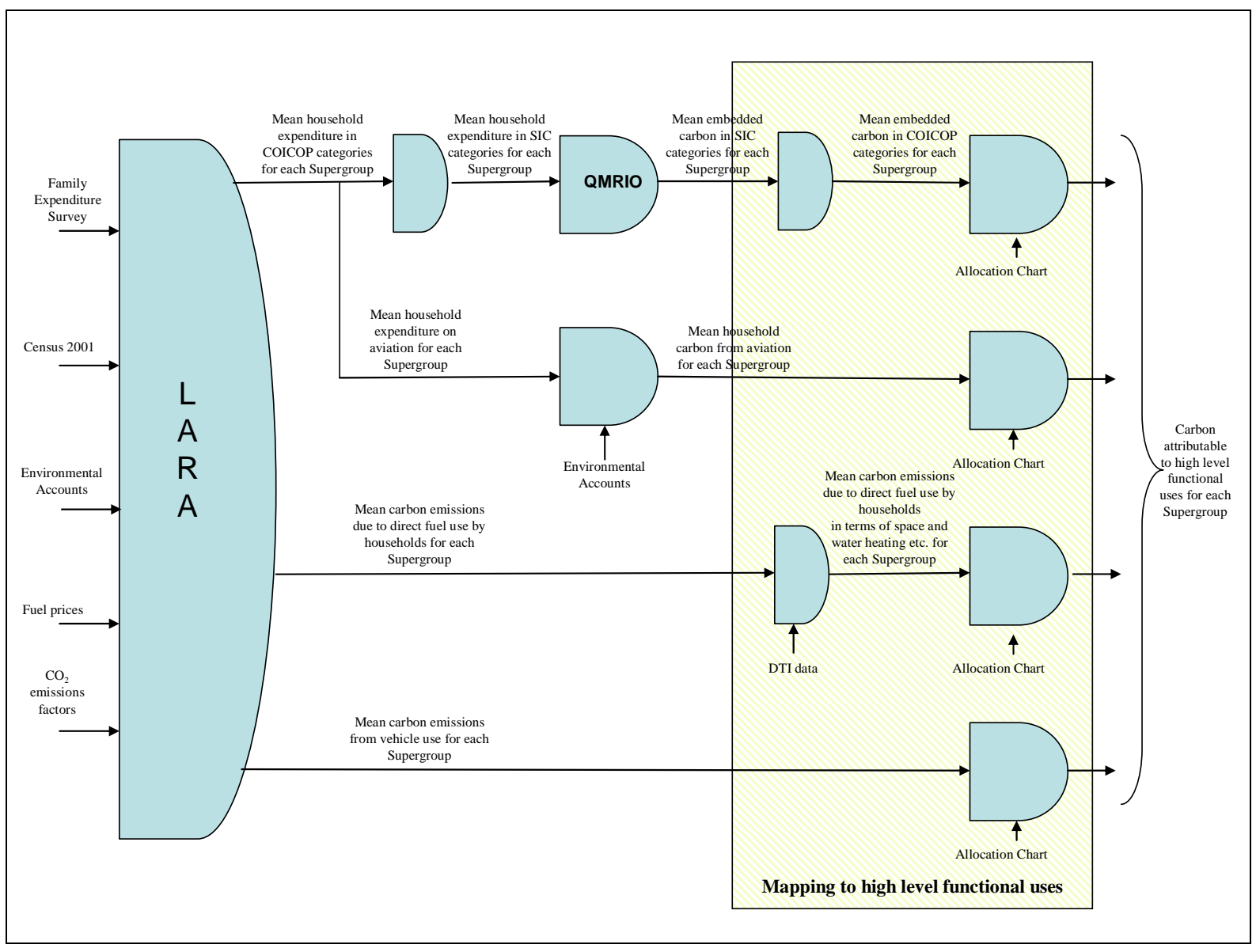

Figure 4. A flow diagram to show estimation of $\mathrm{CO}_{2}$ attributable to Supergroups using LARA, and allocation to high level functional uses

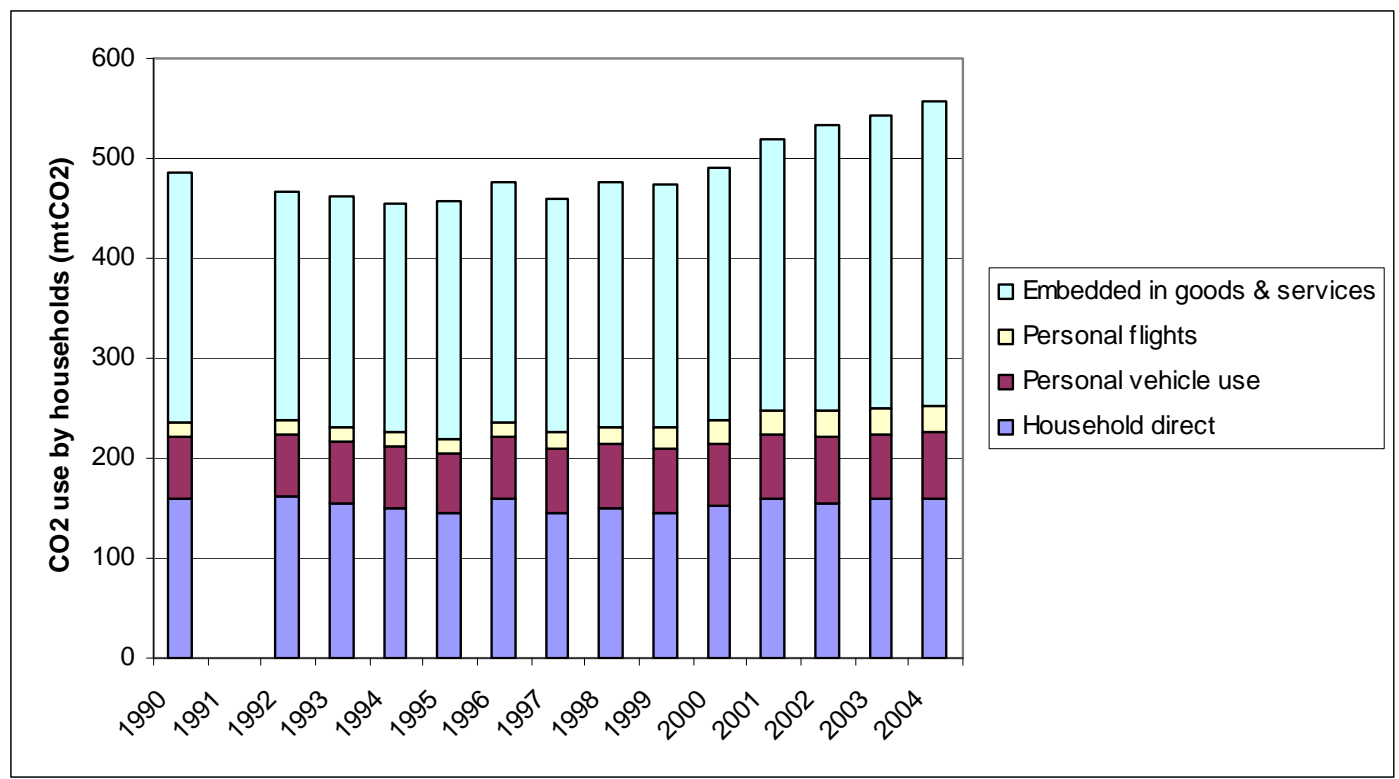

Figure 5. Trends in $\mathrm{CO}_{2}$ attributable to UK households 1990-2004. 


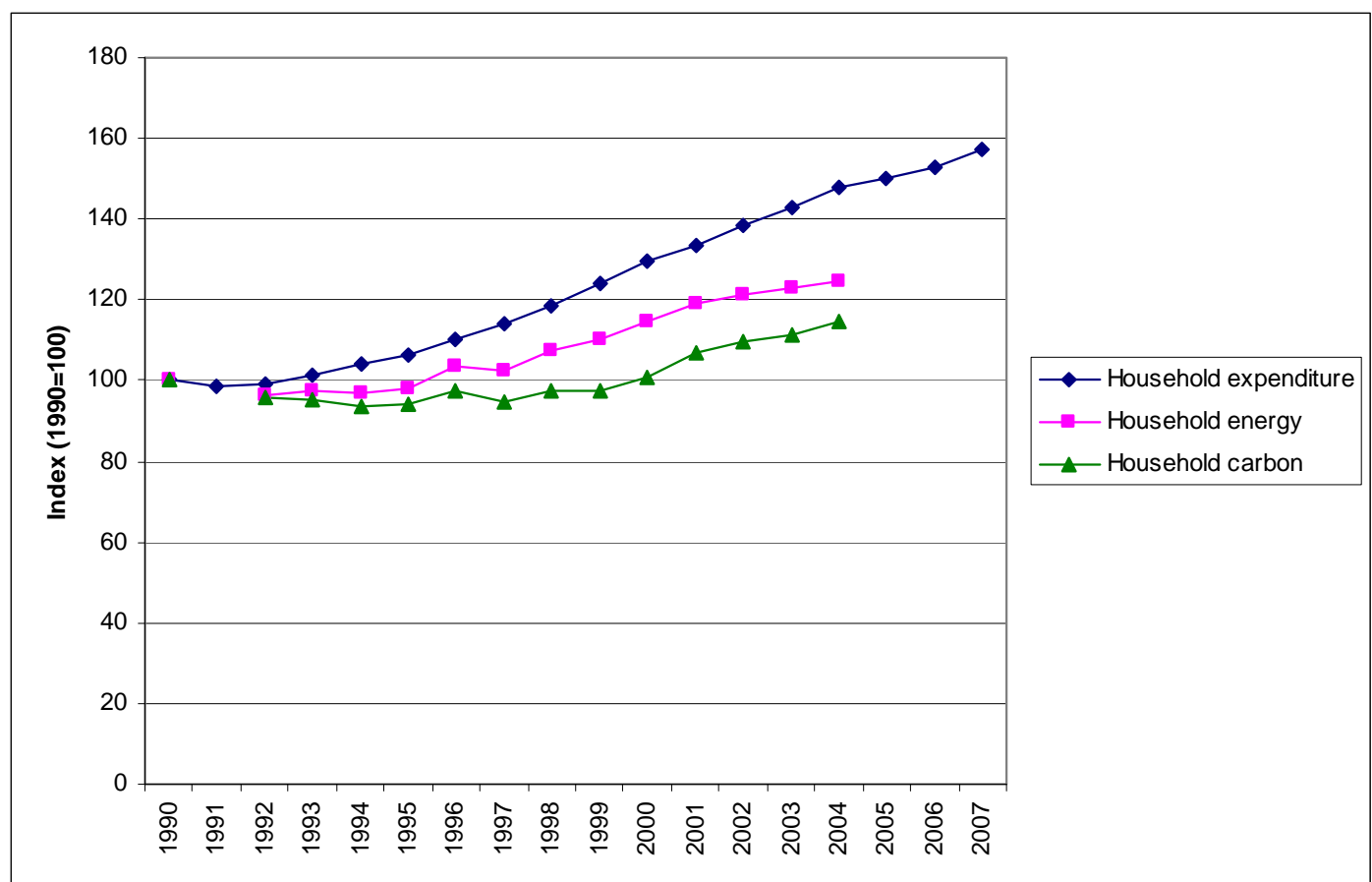

Figure 6. Trends in UK household expenditure, energy use and $\mathrm{CO}_{2}$ indexed to $1990=100$

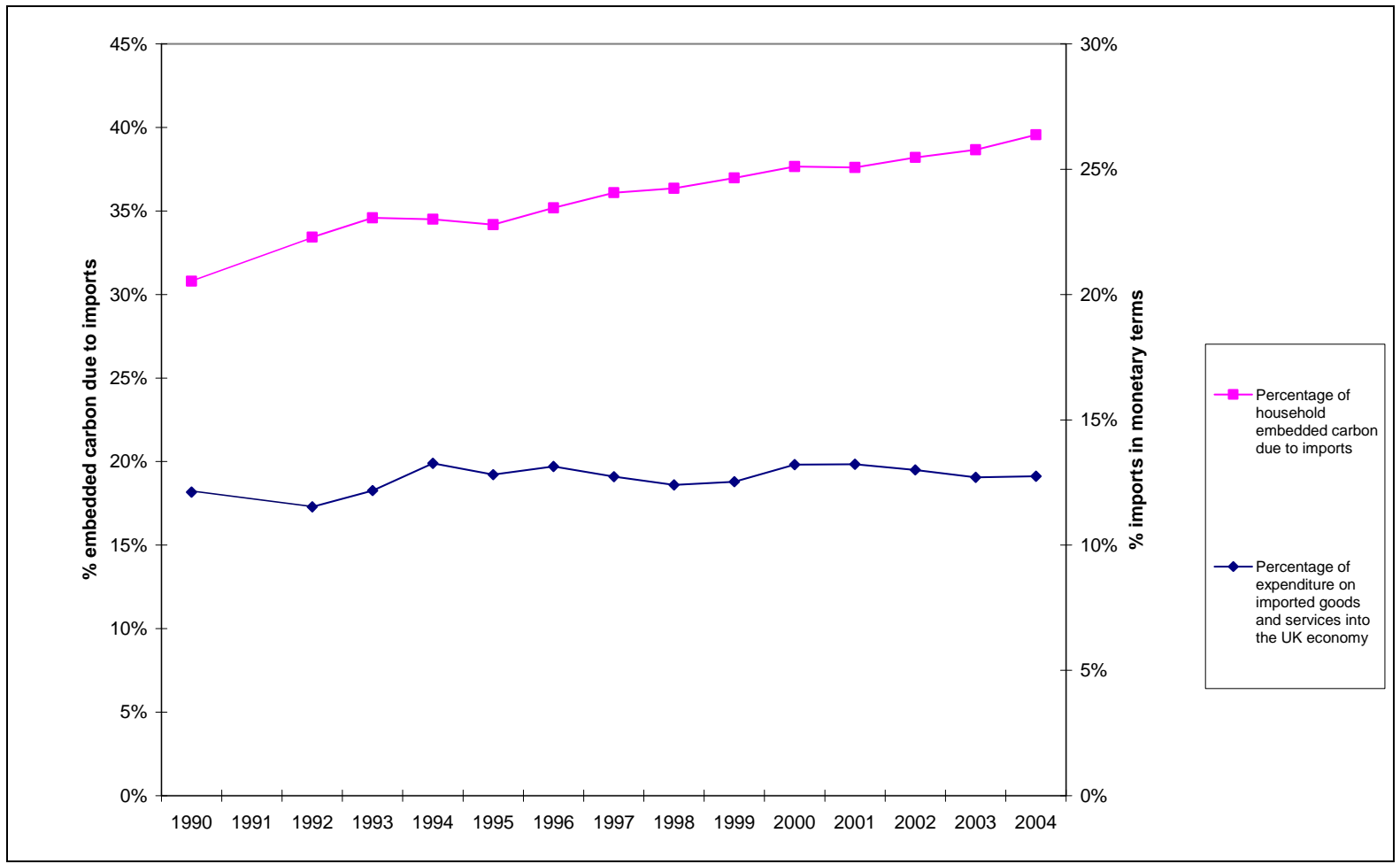

Figure 7. Import trends 


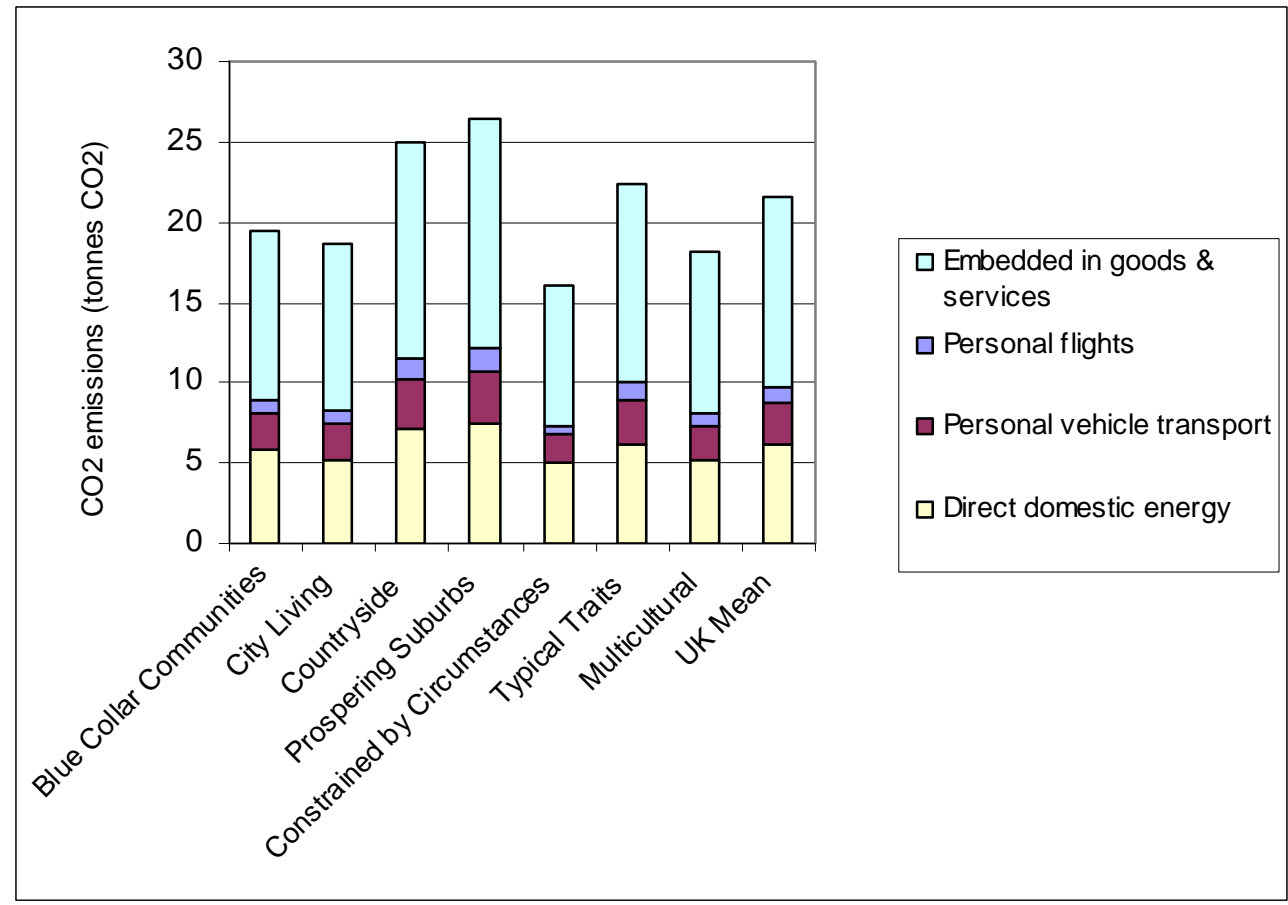

Figure 8. $\mathrm{CO}_{2}$ emissions attributable to Supergroups (2004)

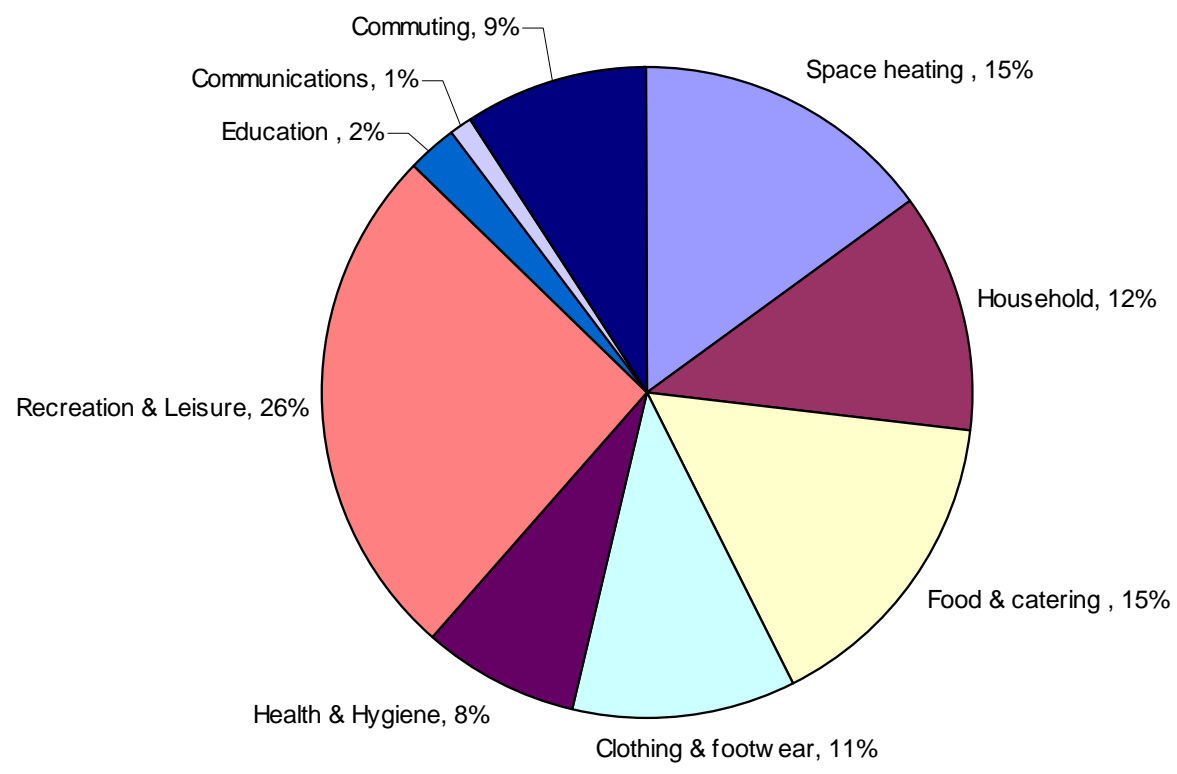

Figure 9. $\mathrm{CO}_{2}$ emissions allocated to high level functional uses for an average UK household (2004) 
Appendix 1. Selected characteristics of Supergroups

\begin{tabular}{|c|c|c|c|c|c|c|c|}
\hline & $\begin{array}{l}\text { Blue Collar } \\
\text { Communities }\end{array}$ & City Living & Countryside & $\begin{array}{l}\text { Prospering } \\
\text { Suburbs }\end{array}$ & $\begin{array}{l}\text { Constrained by } \\
\text { Circumstances }\end{array}$ & Typical Traits & Multicultural \\
\hline $\begin{array}{l}\text { Variables } \\
\text { distinctively } \\
\text { above national } \\
\text { average }\end{array}$ & $\begin{array}{l}\text {-Age 5-14 } \\
\text { - Rent (public) } \\
\text { - Terraced housing } \\
\text { - Lone parent } \\
\text { households }\end{array}$ & $\begin{array}{l}\text {-Age } 25-44 \\
\text {-Population density } \\
\text { - Rent (private) } \\
\text { - Flats } \\
\text { - No central heating }\end{array}$ & $\begin{array}{l}\text {-Age } 45+ \\
\text { - Detached housing } \\
\text {-Rooms per } \\
\text { household } \\
\text {-2+ car households }\end{array}$ & $\begin{array}{l}\text {-Age } 45-64 \\
\text { - Detached housing } \\
\text { - Rooms per } \\
\text { household } \\
\text {-2+ car households } \\
\text { - Two adults no } \\
\text { children } \\
\text { - Households with } \\
\text { non-dependant } \\
\text { children }\end{array}$ & $\begin{array}{l}\text {-Age 65+ } \\
\text { - Single pensioner } \\
\text { households } \\
\text { - Rent (Public) } \\
\text {-Flats } \\
\text {-People room } \\
\text { - Unemployment }\end{array}$ & $\begin{array}{l}\text { Typical traits is } \\
\text { characterised by its } \\
\text { 'averageness'. This } \\
\text { Supergroup has few } \\
\text { values which are } \\
\text { high or low in } \\
\text { comparison to the } \\
\text { other groups. }\end{array}$ & $\begin{array}{l}\text {-Age 0-15 } \\
\text { - Born outside UK } \\
\text {-Population density } \\
\text { - No central heating } \\
\text {-People per room } \\
\text { - Flats } \\
\text { - Unemployment } \\
\text { - Rent (public and } \\
\text { private) }\end{array}$ \\
\hline $\begin{array}{l}\text { Variables } \\
\text { distinctively } \\
\text { below } \\
\text { national average }\end{array}$ & $\begin{array}{l}\text { - Rent (private) } \\
\text { - Flats }\end{array}$ & $\begin{array}{l}\text {-Ages 0-14 } \\
\text { •Rooms per } \\
\text { household }\end{array}$ & $\begin{array}{l}\text {-Population density } \\
\text {-Flats } \\
\text {-People per room } \\
\text { - Single person } \\
\text { household }\end{array}$ & $\begin{array}{l}\text { - No central heating } \\
\text { - Terraced housing } \\
\text { - Flats } \\
\text { - Single person } \\
\text { household } \\
\text { - Rent (private and } \\
\text { public) }\end{array}$ & $\begin{array}{l}\text { - Two adults no } \\
\text { children } \\
\text { - Rent (private) } \\
\text { - Detached housing } \\
\text { - Rooms per } \\
\text { household } \\
\cdot 2+\text { car household }\end{array}$ & & $\begin{array}{l}\text {-Age } 45+ \\
\text { - Single pensioner } \\
\text { households } \\
\text { - Detached housing }\end{array}$ \\
\hline
\end{tabular}

Source: Vickers et al (2005), and Druckman and Jackson (2008c) 
